\title{
Self-financed water bank for resource reallocation to the environment and within the agricultural sector
}

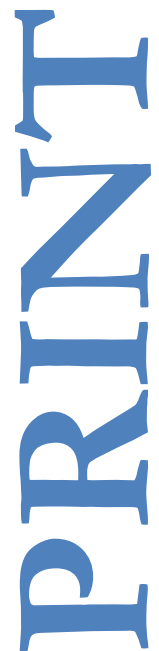

Carlos Gutiérrez-Martín

José A. Gómez-Limón

Nazaret M. Montilla-López

Paper accepted to be published in

\section{Ecological Economics}

\author{
Editorial: Elsevier Science ISSN: 0921-8009
}

https://doi.org/10.1016/j.ecolecon.2019.106493

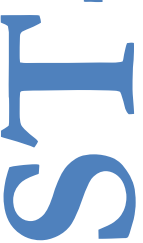

This research is co-financed by the Spanish Ministry of Science,

Innovation and Universities (MCIU) and the European

Regional Development Fund (ERDF) through the project

IRRIDROUGHT (RTI2018-095407-B-I00). 


\title{
Self-financed water bank for resource reallocation to the environment and within the agricultural sector
}

\author{
Carlos Gutiérrez-Martín*, José A. Gómez-Limón and Nazaret M. Montilla-López \\ Water, Environmental and Agricultural Resources Economics (WEARE) Research Group, Universidad de \\ Córdoba, Campus de Rabanales, 14071 Córdoba, Spain
}

\begin{abstract}
In closed river basins, economic activities commonly threaten instream flows, especially during drought episodes. In such situations, a suitable policy option is to recover water for the environment by purchasing water allocations from farmers through a water bank. However, the purchase of temporary water rights strongly depends on the public budget available for this purpose. We propose a self-financed water bank with the twofold objective of reallocating water within the agricultural sector and recovering a share of the purchased water for the environment. The main feature of this water bank is that it will operate in a monopsonymonopoly setting, using its market power to recover water for environmental purposes, and working with a balanced budget (expenditure on purchases will equal revenues from sales). A mathematical programming model is developed to simulate the potential performance of the proposed water bank in the Guadalquivir River Basin (southern Spain), considering society's demand for environmental water and different water scarcity scenarios. Results show that a maximum of between $5.8 \%$ and $10.4 \%$ of total water availability can be recovered for the environment, depending on the severity of the drought, while total economic efficiency is increased, yielding a beneficial result for farmers and society.
\end{abstract}

Keywords: Hydrological drought, Allocation trade, Environmental flows, Economic efficiency, Mathematical programming, Spain.

\section{Highlights}

- Recovering water for the environment through a water bank, without any public spending

- Buying water at low prices and selling only a share of this water at higher prices

- Expenditure on buying water allocations equals revenues from sales

- The more severe the drought, the greater the share of water recovered for the environment

- Total economic efficiency is increased considering productive and environmental surpluses 


\section{Introduction}

In most of the developed countries located in Mediterranean and semi-arid regions, there is strong competition for the use of water and many of their basins are 'closed'. A basin is closed when there is no reasonable possibility of expanding the water supply to meet new demands; indeed, new demands can only be met by reducing the existing ones (Molle et al., 2010). In these basins, demand-side policies are the only option for managing water scarcity; notable examples include economic instruments such as water markets and water banks (Lago et al., 2015).

In closed basins, the environment is often negatively affected by an excessive extraction of water, which jeopardizes the maintenance of the associated ecosystems. In response to this situation, minimum environmental flows have been set. These flows can be considered as water rights held by the public water agency, which cannot be allocated to any other use (LaneMiller et al., 2013). However, in many cases, the allocation of water resources between consumptive uses (mainly irrigation) can result in failure to meet these minimum environmental flows. This may be due to an over-allocation of water rights, exceeding the renewable resources of a certain basin, and/or a situation of hydrological drought ${ }^{1}$ that does not allow the productive and environmental uses of water to be reconciled (Crossman et al., 2010).

Given this situation, there are different ways to recover water for the environment (Crase et al., 2012; Bark et al., 2014): i) investment in water-saving infrastructure (e.g., modernization of irrigation); ii) voluntary transfer of water to the environment; iii) regulatory measures avoiding over-allocation of resources (reduction of water allocations); and iv) the use of market instruments for the acquisition or lease of water rights from the agricultural sector for environmental purposes. There is evidence that market instruments are more cost-effective and considered more acceptable by water users than alternative policy instruments when recovering water for environmental purposes (Connor et al., 2013). Thus, the implementation of these economic instruments is becoming increasingly common in many regions of the world that are facing environmental problems characteristic of mature water economies.

Among the market instruments used for the recovery of water for environmental purposes, we can identify two main types of arrangements. On the one hand, there is the public purchase of water rights or entitlements, also known as 'buy-back', which allows water to be recovered permanently in those regions with over-allocation of resources. The primary example of this

\footnotetext{
${ }^{1}$ Although the term "drought" is used to describe different water scarcity phenomena (see Wilhite and Glantz, 1985 for more details), such as meteorological drought (below-average rainfall) or agricultural drought (deficiency of soil moisture negatively affecting crop yields), it is worth pointing out that this paper is focused on the management of hydrological droughts. This kind of drought can be defined as an episode in which instream flows fall below the level required to properly supply established uses under a given water management system, such as irrigation or environmental instream flows.
} 
instrument is the Restoring the Balance Program, implemented in the Murray-Darling Basin in Australia, which has cost $\sim$ AUD2.5 billion (Grafton and Wheeler, 2018).

On the other hand, allocation trade (leasing or temporary reallocation of water rights) is used in cases where it is necessary to temporarily recover water for the environment in a cyclical way (e.g., during hydrological drought events). Examples of these public temporary rights acquisitions include the case of California during the different drought episodes that occurred between 1982 and 2011 (Hanak and Stryjewski, 2012).

Based on these instruments, water rights and allocation trade, a series of derivative instruments have been developed. These include: i) long-term temporary contracts; ii) countercyclical trade, in which allocations are bought in times of abundance and stored for later environmental use or occasionally for resale to farmers (Kirby et al., 2006); iii) covenants, that is, purchase and sale of rights with changes in their characteristics (modified conditions of use, reduced guarantee, etc.) (Scoccimarro and Collins, 2006); iv) leaseback, which allows an environmental agency to buy permanent rights but lease them in years of abundance through spot markets (Lane-Miller et al., 2013); and v) options markets, where an environmental agency pays a premium and thereby reserves the right to purchase water in case of environmental need (Hafi et al., 2005).

The implementation of all these environmental purchases has relied on so-called 'water banks', a set of market instruments supported by an institution, usually of a public nature, which centralizes all market operations, both purchases and sales. These banks can act as simple intermediaries aiming at a more efficient reallocation of water resources among productive water users (buying and selling rights or allocations), performing a similar function to water markets. However, these banks can also play a relevant role in making purchases for environmental purposes, that is, public purchases of rights or allocations without subsequent resale (Montilla-López et al., 2016).

Public budget constraints are a major obstacle to the establishment of water banks for environmental purposes (Burke et al., 2004; Schilizzi and Latacz-Lohmann, 2013). In order to overcome this problem, we propose a potential solution based on a self-financed public water bank that operates during drought periods by buying and selling water allocations (allocation trade), with the dual purpose of reallocating water among productive users and acquiring water for environmental purposes. The key feature of this self-financed water bank is that it will operate in a monopsony-monopoly setting (no other water markets will be allowed). In this setting, a public agency managing the bank should first act as the sole buyer (monopsony market) of water allocations by organizing public purchase offers of temporary water rights. Subsequently, this agency also acts as the sole seller (monopoly market) of those purchased allocations, by organizing a public sale offer. Under this market arrangement, the water agency can use its market power to create a gap between purchase and sale prices (purchase price 
lower than sale price), and to reallocate water between productive users by purchasing more water than will be sold. The difference between the volume of water purchased and sold can be allocated to improve environmental flows. Moreover, because of the difference in purchase and sale prices, this water bank can balance expenditure on purchases (a larger volume at a lower purchase price) with the revenues from sales (a smaller volume at a higher sale price). Thus, this market institution can operate without the support of any additional public budget.

The main objective of this paper is to simulate the potential performance of the proposed self-financed water bank for a real case study (the Guadalquivir River Basin in southern Spain). The methodological approach used to simulate this water bank setting is mathematical programming, since it has proved useful in ex-ante analyses of the performance of this kind of market instrument. This simulation will enable an assessment of whether the implementation of this economic instrument can contribute to improving public water management during cyclical scarcity periods (drought events), reflected in economic efficiency gains.

Among the previous empirical studies in this line, it is worth mentioning that of MontillaLópez et al. (2018a), who focused on water banks for allocation trade aimed at improving water-use efficiency by reallocating resources among productive users (irrigators), or Connor and Kaczan (2013) and Pérez-Blanco and Gutiérrez-Martín (2017), who examine water banks for allocation trade aimed at increasing environmental flows. However, in the reviewed literature there are virtually no studies on water banks that handle dual-purpose allocation trade (both for improving the efficiency of water use among productive users and for increasing environmental flows), similar to the one proposed here. As far as the authors are aware, only two slightly related works can be found in the existing literature. The first one is the paper by Kirby et al. (2006), who suggest that an environmental agency should possess water rights and operate in an existing spot market in order to optimize environmental flows by buying, selling and storing water between seasons. Relying on a different rationale, Qureshi et al. (2007) develop a model in which a quantity of water is recovered for the environment by imposing a constraint on the agricultural water supply (reduced water allotments) and allowing farmers to freely trade their allocated water resources.

In this sense, it is worth pointing out that the abovementioned self-financed water bank is an innovative proposal and represents a contribution to the existing literature; it has been shown to be an interesting policy alternative aiming at improving water management during drought periods in basins where public budget constraints make it difficult to implement other economic instruments.

In order to achieve the objective indicated above, this paper is structured as follows. After this introduction, the second section presents the analytical framework used to assess the performance of the proposed water bank, based on an economic analysis accounting for gains 
in economic efficiency. This analytical framework has allowed us to consider two different operational strategies for this bank; one aimed at maximizing the volume of water recovered for the environment, and the other at maximizing economic efficiency considering the social demand for environmental water. The third section describes the features of the Guadalquivir River Basin (southern Spain), taken as a real case study for the empirical application of the proposed economic analysis. Next, the fourth section explains the mathematical programming models used to simulate the behavior of the economic agents (water users) and the public environmental agency managing the proposed water bank, allowing the empirical assessment of its performance. The fifth section summarizes the main results obtained, which are discussed in more depth in section six. Lastly, the seventh section concludes, pointing out the main lesson learned for policy-making.

\section{Self-financed water banks}

The operational strategies of the proposed self-financed water bank are simple. However, in order to assess its potential performance, we consider different institutional arrangements or scenarios as benchmarks. The baseline scenario to be considered is the one without any water trading options, where all users can only use the resources associated with their own water rights. This scenario is the one currently in place in the case study analyzed (trade operations are negligible) and is taken as the reference for the comparative analysis with the other alternative scenarios. Scenario 1 is a public bank for reallocation of water (allocation trade) between productive users, as is currently operating in other many regions. Scenarios 2 and 3 are two different alternatives to the proposed self-financed water bank for dual-purpose allocation trading (reallocation between productive users and the environment). Below, these three alternative institutional arrangements for the water bank (Scenarios 1, 2 and 3) are explained in more detail, indicating how to assess the improvement in economic efficiency that each of these alternatives entails compared with the baseline scenario (no trade).

\subsection{Water bank for the reallocation between productive users (Scenario 1)}

In a closed basin where there is no active water market, a public water bank for temporary (one season) reallocation of water among productive users is a useful instrument to improve productive efficiency (economic efficiency considering only productive activities), especially during drought or cyclical scarcity events (Medellín-Azuara et al., 2013; Montilla-López et al., 2016). In such a water bank, the agency operating the bank launches a public offer to purchase temporary water rights at a fixed price. This offer would be attractive for all those users with a marginal value of water lower than the set purchase price. After purchasing water allocations, the water bank launches a public offer to sell the temporary water rights previously bought at a fixed price to willing buyers, namely, those users with a marginal value of water higher than the set sale price. 
The objective of a non-profit water bank of this kind should be to maximize productive efficiency by properly reallocating water resources between productive users. As the economic theory points out (Pindyck and Rubinfeld, 2013, p. 323), productive efficiency is maximized when the sum of the efficiency gains generated by sales and purchases is maximized. In this regard, the efficiency generated by the water bank purchases is calculated through the producer surplus $\left(S_{p}\right)$, measuring the profit beyond the marginal value of water that a water user obtains when he or she sells his/her water allocation to the bank instead of using it (if water allocations are sold at a price $P_{p}$ as shown in Figure 1a, then $S_{p}=P_{p} A P_{p}^{0}$ area under the water supply curve $Q_{p}$ ). On the other hand, the efficiency generated by the water bank sales is calculated through the consumer surplus $\left(S_{s a}\right)$, accounting for the surplus that water users gain when they purchase the water from the bank at a price lower than their marginal value of water (if water allocations are bought at a price $P_{s}$, then $S_{s a}=P_{s a}^{0} A P_{s}$ area under the water demand curve $\left.Q_{s a}\right)^{2}$

Considering this theoretical framework, it is worth pointing out that the efficiency assessment for the baseline scenario (no trade) is null $\left(S_{p}=S_{s a}=0\right)$ because $Q_{p}=0$ and $Q_{s a}=0$. As this scenario is taken as a benchmark, it should be noted that all efficiency assessments for the rest of the water bank scenarios should be considered as improvements over this baseline scenario.

For the sake of simplicity, transaction costs have not been considered in the economic analyses developed to explain the optimum performance of all water bank scenarios proposed in this paper. However, it is worth pointing out that there is evidence to show that actual transaction costs, both operational and institutional (McCann et al., 2005), could entail a leftward shift in the supply and demand curves relative to those depicted in Figures 1 and 2, depending on who bears these costs (buyers and/or sellers, respectively). These shifts would ultimately lead to a depressing effect on the allocation transfers and the efficiency gains. An approximation of the implications of the existing transaction costs for the performance of the water bank scenarios proposed is presented in the discussion section.

\footnotetext{
${ }^{2}$ In this paper, all quantities $\left(Q_{x}\right)$ and prices $\left(P_{x}\right)$ have been labeled in reference to the action performed by the agency managing the water bank. Thus, the purchase of allocations by the bank (water supply curve) are denoted by subscript ' $p$ ': $Q_{p}$ and $P_{p}$. The sale of allocations to agricultural users (agricultural water demand) are labeled with the subscripts ' $s a$ ' and ' $s$ ': $Q_{s a}$ and $P_{s}$. The difference between $Q_{p}$ and $Q_{s a}$ is the allocations devoted to environmental purposes $\left(Q_{s e}\right)$, with the subscripts ' $s a$ ' and ' $s e$ ' distinguishing the two destinations of the allocations sold by the bank.
} 
1a. Scenario 1:

Maximum productive efficiency

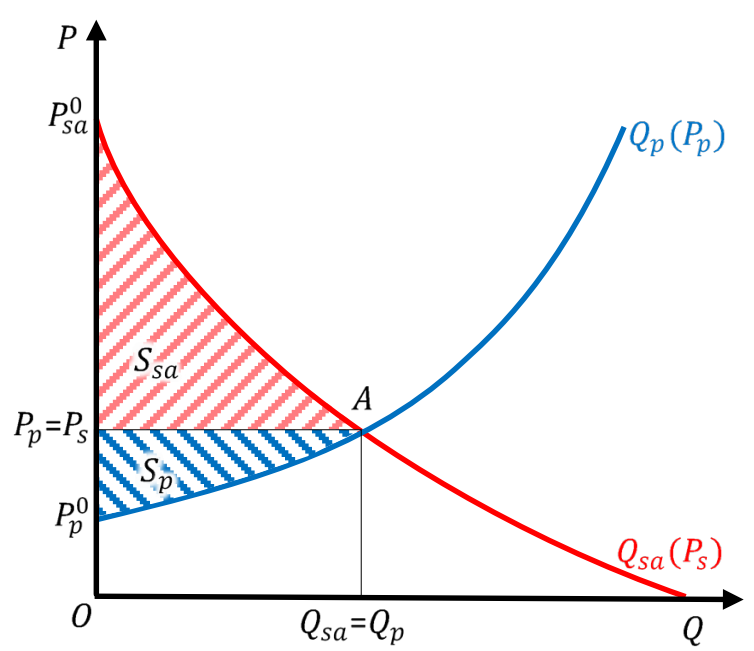

1b. Scenario 2:

Maximum volume of water

for the environment

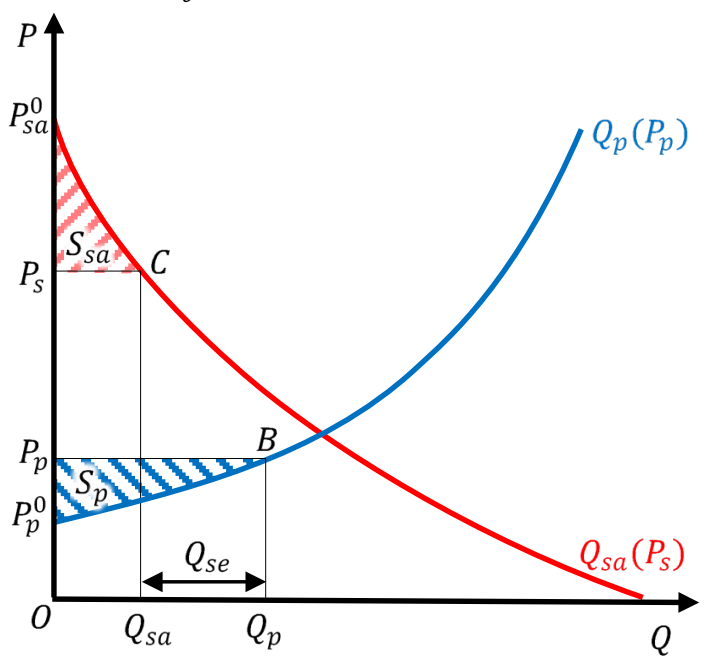

Fig. 1. Water bank Scenarios 1 and 2. Supply and demand for water allocations

\subsection{Maximizing the volume of water for the environment (Scenario 2)}

During a hydrological drought, not only are consumptive uses affected, but the instream flows are also diminished. In such a situation, the public water agency could mitigate this effect by acquiring water for the environment without the need for additional public funds, using its monopsony-monopoly position within the water bank. The resulting water reallocation bank would have the dual purpose of reallocating temporary rights among productive users and recovering the maximum amount of water for the environment. In order to achieve this objective without consuming additional public budget resources, this selffinanced bank should balance the expenditure on public purchase offers and the revenue obtained through public sale offers. This cash-flow balance can be achieved by buying a smaller volume of water at a lower price than in Scenario 1, and selling only part of the volume purchased, and at a higher price than the sale price in Scenario 1.

Figure $1 \mathrm{~b}$ shows how this idea is executed. For Scenario 2, it can be observed how a quantity of water $Q_{p}$ is purchased by the bank at a price $P_{p}$ determined by the supply curve of water users $Q_{p}\left(P_{p}\right)$ (see point B), while a smaller amount of water $Q_{s a}$ is sold at a higher price $P_{S}$ determined by the demand curve of water users $Q_{s a}\left(P_{S}\right)$ (see point $\mathrm{C}$ ). The difference between the amount of water purchased $Q_{p}$ and subsequently sold $Q_{s a}$ is allocated to the environment $\left(Q_{s e}\right)$ (i.e., $\left.Q_{p}=Q_{s a}+Q_{s e}\right)$, while the budget is balanced since the revenue represented by the area $P_{s} C Q_{s a} O$ is equal to the expenditure represented by the area $P_{p} B Q_{p} O$ in the absence of transaction costs (i.e., $P_{p} \cdot Q_{p}=P_{s} \cdot Q_{s a}$ ). Although multiple alternative operation strategies can fulfill both constraints, under Scenario 2 it is assumed that the water 
bank operation entails maximizing the amount of water allocated to the environment $\left(Q_{s e}\right)$. Thus, a single optimum solution is achieved for Scenario 2.

Regarding efficiency, both producer and consumer surpluses can be quantified in this case by the areas $P_{p} B P_{p}^{0}\left(S_{p}\right)$ and $P_{s a}^{0} C P_{s}\left(S_{s}\right)$. This means that this scenario also produces an improvement in productive efficiency compared to the baseline scenario (no trade). However, it can also be noted that despite this improvement, productive efficiency gains are lower than those achieved in Scenario 1. Therefore, this scenario could be considered a 'second best' option for the water bank, as there is a reduction in productive efficiency compared to Scenario 1 because of the monopsony-monopoly power exerted by the water bank in order to recover the maximum amount water for the environment. Thus, by lowering the purchase price $P_{p}$ and increasing the sale price $P_{S}$ in relation to the competitive equilibrium (Scenario 1), both producer and consumer surpluses are reduced in Scenario 2, limiting the productive efficiency improvement achieved.

\subsection{Maximizing economic efficiency considering the social demand for environmental water} (Scenario 3)

Regarding the optimum solution for Scenario 2, it is worth pointing out that the environmental water also generates an economic efficiency that has not been considered in the previous analysis. Similar to consumer surplus for purchases by productive users $\left(S_{s a}\right)$, there is another kind of consumer surplus for resources recovered for environmental uses (environmental surplus, $S_{\text {se }}$ ). However, the latter surplus can only be assessed if the social demand for environmental water is taken into account. This surplus can be measured as the extra benefit that society gains when environmental water is obtained from the water bank at a cost below its maximum marginal social value, which is determined by society's demand curve for environmental water.

Scenario 3 considers a water bank aimed at maximizing economic efficiency gains, also accounting for the surplus generated by resources recovered for environmental uses, $S_{s e}$. This scenario is represented in Figure 2. The marginal value that society attributes to environmental water $(V)$ is considered to be zero when the instream water flows are the same than those existing in an average hydrological year $\left(Q_{s e}^{\max }\right)$. Moreover, it is also assumed that this social value increases as the gap between current flows and those corresponding to an average hydrological year increases. The marginal value of environmental water increases up to a maximum environmental value $V^{0}$, at which point the flows in the water bodies are those set as minimum environmental flows. 


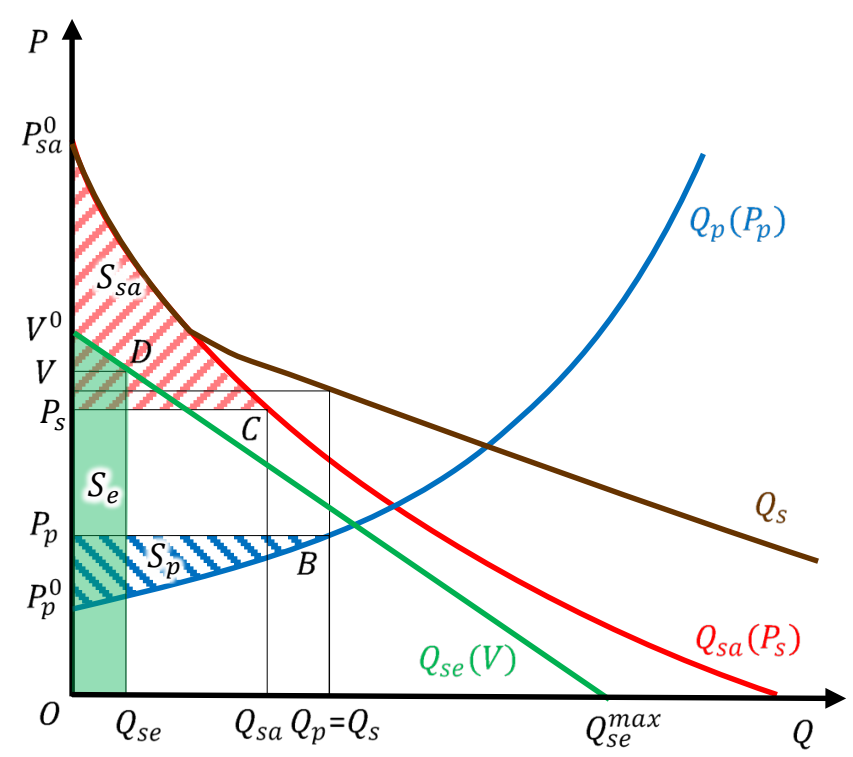

Fig. 2. Water bank Scenario 3: Maximum economic efficiency considering the social demand for environmental water

Introducing society's demand curve for environmental water $Q_{s e}(V)$ into the analysis, this demand must be added to the productive water demand $Q_{s a}\left(P_{S}\right)$ to give an aggregate demand $Q_{S}$ for productive and environmental water (see Figure 2). Within this framework, a public water agency could implement a water bank aimed at maximizing total economic efficiency. To achieve this objective, the bank should reallocate water resources among productive users and the environment, while meeting just two constraints: financial balance (expenditure equal to revenues; $P_{p} \cdot Q_{p}=P_{s} \cdot Q_{s a}$ ) and water balance (i.e., water purchased must equal water sold plus water recovered for the environment; $Q_{p}=Q_{s a}+Q_{s e}$ ).

Figure 2 shows a hypothetical solution for Scenario 3. The optimal solution will be at $B$ for purchases, $C$ for productive sales and $D$ for environmental water. As in the previous scenario, in order to guarantee that the water bank is self-financed, revenue for the water bank at point $C$, defined by the area $P_{S} C Q_{s a} O$, equals expenditure for the bank at point $B$, measured as the area $P_{p} B Q_{p} O$. Moreover, the water balance condition is met since the volume of water purchased $\left(Q_{p}\right)$ equals the volume of water sold $\left(Q_{s a}\right)$ plus the volume of water recovered for the environment $\left(Q_{s e}\right)$. The efficiency $S_{p}$ related to the water bank's purchases (producer surplus) is equivalent to the area $P_{p} B P_{p}^{0}$, the efficiency $S_{s a}$ linked to the water bank's sales to productive users (consumer surplus) is measured by the $P_{s a}^{0} C P_{s}$ area, and the efficiency $S_{s e}$ derived from the amount of environmental water generated by the water bank (environmental surplus) is $V^{0} D Q_{s e} O$. The optimal solution achieved is the one where the summation $S_{p}+$ $S_{s a}+S_{s e}$ is maximized.

It should be noted that the public water agency managing the water bank can use its monopsony-monopoly power to distinguish between water uses (productive and 
environmental) in an attempt to achieve the maximum total economic efficiency. Thus, the marginal value of the water sold to productive uses (i.e., the sale price $P_{s}$ ) can diverge from the marginal value of the water devoted to environmental uses $(V)$.

As can be easily seen in Figure 2, solutions obtained for Scenario 3 involve lower purchase prices $P_{p}$ and higher sale prices $P_{S}$ compared to the competitive equilibrium (Scenario 1); thus, both producer and consumer surpluses generated by productive users are reduced. However, Scenario 3 considers an increase in the environmental efficiency generated because of the water recovered by the bank to improve instream flows. In any case, under Scenario 3, the overall variation of the three surpluses considered (producer, consumer and environmental) would lead to total economic efficiency gains compared to Scenario 1, since the monopsonymonopoly strategy adopted by the water agency would be aimed at maximizing the summation $S_{p}+S_{s a}+S_{s e}$.

\section{Case study: The Guadalquivir River Basin}

The Guadalquivir River Basin (GRB) is located in southern Spain and covers a total area of $57,184 \mathrm{~km}^{2}$. The basin mostly lies in Andalusia, in a semi-arid region with a typical Mediterranean climate. The average annual rainfall of $573 \mathrm{~mm}$ is irregularly distributed both spatially and temporally, with frequent episodes of extreme droughts and floods. Currently, the GRB is closed to new users (Berbel et al., 2013) because of the increase in water demand over the past few decades, mainly due to the growth of irrigated areas, and the impossibility of further increases in the water supply. As a result, demand-side management has become the only tool available for managing new water demands.

Regarding demand-side policies, the Spanish Water Act passed in 1999 allows for the implementation of water banks, which are called 'water exchange centers'. These water exchange centers act only in "exceptional situations of water scarcity" (special drought situations or severe overexploitation of aquifers). However, the procedure to set up water banks in Spain involves a protracted administrative process, as part of which the Cabinet authorizes the basin authority to open and manage the water exchange center and approves the public budget available for the water bank operations. Moreover, although water banks are legally allowed to implement purchase (public purchase tenders) and sale (public sale offerings) operations, usually only the first type are actually carried out, since the public sale of water rights or water allocations is regarded as politically and socially unacceptable (water rights and water allocations are normally granted to users for free by the basin authority, and bank sales could be considered discriminatory). This makes water banks an expensive instrument for the public sector to implement, requiring substantial budgetary resources. Indeed, they have only been implemented to manage situations of structural over-extraction of groundwater bodies through the permanent purchase of water rights, and to manage situations of extreme drought, improving instream flows through seasonal allocation trade 
(Palomo-Hierro et al., 2015). Although the GRB also faces structural problems of overextraction, and allocation trade could be a suitable instrument to cope with drought management and improve instream flows, water banks have not yet been used as an instrument to reallocate water resources in this basin due to the lack of political will to implement them (Montilla-López et al., 2016). Thus, this is an interesting case study for an ex-ante evaluation of the performance of water banks.

Agriculture is the primary consumer in the GRB since irrigated land covers approximately $28 \%$ of the agricultural area in the basin (Expósito and Berbel, 2017) and accounts for $88 \%$ of the total water demand at the basin level (an average of $3357 \mathrm{Mm}^{3}$ annually). Households and other urban demands use an average of $379 \mathrm{Mm}^{3}$ per year (10\% of total demand) (CHG, 2015). However, it is worth pointing out that the agricultural sector is the most vulnerable user in the event of water shortages (droughts) due to the priority system established by the 1985 Spanish Water Law. This system grants priority rights to the urban uses (including domestic uses, municipal services, public gardening, and small industries connected to urban water networks); that is, urban water demands are met first when there is not enough water available to cover all the demands. Once urban rights have been fulfilled, the remaining water can be delivered to agricultural and other productive uses, although allotments are reduced proportionally to all irrigators. This legal framework explains why the reallocation of water resources through market instruments is expected to be implemented only within the agricultural sector. Accordingly, only irrigators are considered as potential agents operating in the water bank proposed here.

In this sense, it is also worth pointing out that $84 \%$ of the total irrigated area in the basin is located in the same hydrological system (Regulación General), which is managed by a public water agency (Confederación Hidrográfica del Guadalquivir, CHG) operating welldeveloped storage and conveyance infrastructures. These features mean that any water exchanges between the irrigators within this system are feasible. There are only a few irrigators within the GRB -those that are still not connected to the CHG delivery systems - who face physical barriers to trade (Berbel et al., 2013; Giannoccaro et al., 2013).

The GRB has an average flow to the sea of $7092 \mathrm{Mm}^{3}$ a year (CHG, 2015). However, there are large interannual variations in flows due to drought and flood episodes, which in dry years can result in very low instream flows. The legal priority system established under Spanish law also stipulates that a minimal ecological flow should be met before allocating water to irrigation, in order to guarantee the resilience of environmental services to society. This ecological flow accounts for $305 \mathrm{Mm}^{3} /$ year (CHG, 2015). In any case, it is worth pointing out that when actual flows are at the level of these minimal ecological flows, the environment suffers notable damages. As a result, there is a social demand for improving the situation by recovering water from productive uses and returning it to the environment. Therefore, the 
water bank proposed here could be a suitable instrument that benefits the environment and society.

All the features explained above justify the choice of the GRB as the case study for the empirical implementation of the dual-purpose water bank proposed here.

\section{Modeling approach}

\subsection{Aggregate supply and demand curves at the basin level}

In general, farmers whose marginal value of water is low would be willing to sell water to the water bank, while those with a higher marginal value would be willing to buy water from it. Therefore, heterogeneity in the marginal value of water within the agricultural sector is the basic premise behind successful water trading. In a previous study, Montilla-López et al. (2018a) have provided evidence that this premise is met in the GRB, based on interviews with 355 farmers from representative irrigated districts of the basin. These authors grouped the selected sample of farmers into farm types using the cluster analysis technique, thereby establishing 15 farm types with different marginal values of water (i.e., different willingness to sell and to buy water). These farm types described in the work of Montilla-López et al. (2018a) are considered as the agents who will potentially be operating in the proposed water bank.

For each of these farm types (potential buyers and sellers), Montilla-López et al. (2018a) also built a mathematical programming model to simulate their trading behavior within a water bank framework (decisions regarding the sale and purchase of water allocations). These models rely on multi-attribute Cobb-Douglas utility functions, calibrated through weighted goal programming. In summary, it should be noted that the purchase decisions (willingness to pay) and sale decisions (willingness to accept) of each type of farm are based on the maximization of the utility of the irrigator managing each farm type (a function considering the expected profit, the risk assumed and the complexity of management), subject to a series of physical (land and water availability), technical (permanent crop requirements, herbaceous crop rotations and availability of irrigation techniques), market (e.g., commercial channel limitation for perishable vegetables) and policy (e.g., cotton quotas) constraints. Readers interested in the technical details of this modeling approach should refer to Montilla-López et al. (2018b).

After calibrating these models for each farm type, Montilla-López et al. (2018a) simulated their trading behavior by parameterizing the water price. Using this method, they obtained the individual supply and demand curves which describe how each farm type reacts to public offers to purchase water allocations and public offers to sell water allocations, respectively. It is worth pointing out that these parameterizations have been carried out three times to simulate three scenarios of droughts with different levels of water availability: 'moderate' drought, 
where only $75 \%$ of water rights are available; 'severe' drought, where only $50 \%$ of water rights are available; and 'extreme' drought, where only $25 \%$ of water rights are available. These scarcity scenarios are labeled as A75\%, A50\% and A25\%, respectively. After obtaining the supply and demand curves of the simulations for each farm type and drought scenario, Montilla-López et al. (2018a) aggregated them to obtain the corresponding supply and demand curves at the basin level, which are ultimately used for simulating the water bank operations ${ }^{3}$.

The present research has taken the abovementioned aggregate curves as the input for the empirical analysis performed. However, it is worth pointing out that these curves are, in fact, made up of the union of numerous points in the price-quantity space obtained during the parameterization carried out. In order to be able to operate with these curves in an algebraic way, and thus enable the optimization of the programming models built to simulate water bank operations (see sections 4.2 to 4.4 ), we have approximated these aggregate curves as polynomial functions using statistical regression techniques. These polynomial functions are shown in Figure 3.

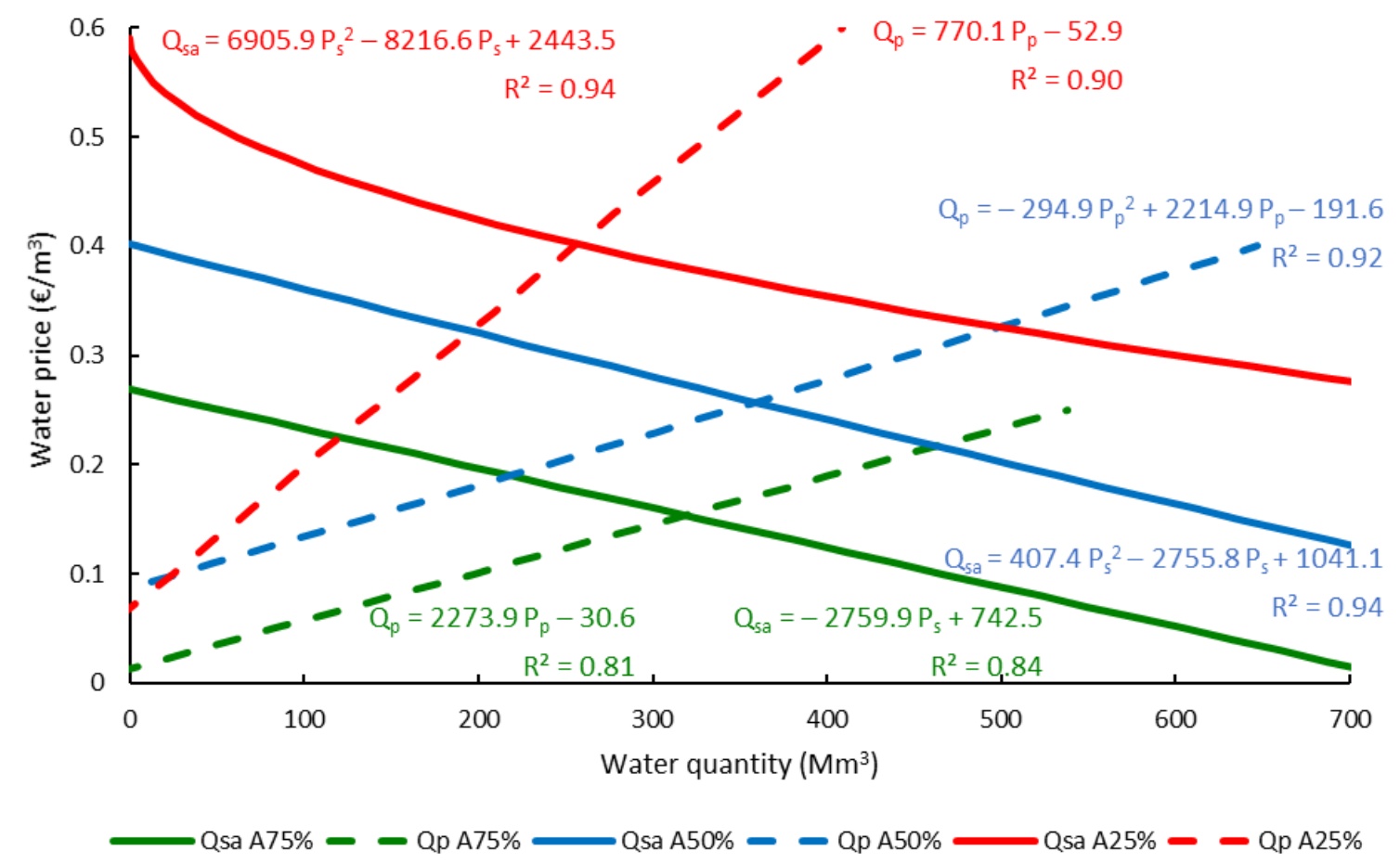

Fig. 3. Regressions of aggregate supply $\left(Q_{p}\left(P_{p}\right)\right)$ and demand $\left(Q_{s a}\left(P_{s}\right)\right)$ curves for the three drought scenarios considered

\footnotetext{
${ }^{3}$ Drought scenarios have been considered as deterministic events because in the GRB annual water allocations granted to farmers for the whole irrigation season (from May to September) are set by the River Basin Agency at the end of April, depending on the volume of water stored in the GRB reservoir network at that time. Farmers thus know definitively the maximum volume of water available for the irrigation season, allowing them to make certain decisions about how much to use on his/her own farms and how much to trade.
} 


\subsection{Water bank for reallocation among agricultural users (Scenario 1)}

In the model built to simulate Scenario 1, the bank acts only as an intermediary between buyers and sellers without having any influence on the market's equilibrium prices or the quantities traded. Thus, the results from this model should be equal to those of a competitive water market. In such a model, the objective of the water bank is to maximize the productive efficiency $\left(S_{\text {prod }}\right)$ derived from purchases and sales, measured as the producer and consumer surplus. Based on Figure 1a, this model has been built as follows:

$\operatorname{Max} S_{\text {prod }}=S_{p}+S_{s a}$

subject to:

$$
\begin{aligned}
& S_{p}=\int_{P_{p}^{0}}^{P_{p}} Q_{p}\left(P_{p}\right) d P_{p} \\
& S_{s a}=\int_{P_{s}}^{P_{s a}^{0}} Q_{s a}\left(P_{s}\right) d P_{s} \\
& Q_{p}=Q_{s a} \\
& Q_{p}=Q_{p}\left(P_{p}\right) \\
& Q_{s a}=Q_{s a}\left(P_{s}\right) \\
& P_{p} \cdot Q_{p}=P_{s} \cdot Q_{s a}
\end{aligned}
$$

Equations (1.2) and (1.3) represent the producer and the consumer surplus, respectively, measured as the area under the $Q_{p}\left(P_{p}\right)$ and $Q_{s a}\left(P_{s}\right)$ curves on the ordinate axis. That is, they represent the productive efficiency gains from water bank purchases $\left(S_{p}\right)$ and from water bank sales to the agricultural sector $\left(S_{s a}\right)$. Equation (1.4) represents volumes traded, both on the supply $\left(Q_{p}\right)$ and the demand $\left(Q_{s a}\right)$ sides. Equation (1.5) represents the water quantity purchased by the bank, which in turn is the supply curve from farmers in Figure 1a $\left(Q_{p}\left(P_{p}\right)\right)$, while (1.6) represents the water quantity sold to farmers, corresponding to farmers' demand curve for irrigation water $\left(Q_{s a}\left(P_{s}\right)\right)$. Equation (1.7) ensures financial balance, where expenditure on acquiring water allocations $\left(P_{p} \cdot Q_{p}\right)$ is offset by revenue from selling water allocations to willing buyers $\left(P_{S} \cdot Q_{s a}\right)$.

\subsection{Water bank for maximizing the volume of water for the environment (Scenario 2)}

As mentioned above, a basin water authority concerned about low instream flows could use its monopsony-monopoly position within a public water bank to deliver water to the environment without spending any public budget. Scenario 2 (see Figure 1b) simulates the maximum amount of water that the water bank can recover for environmental use while keeping a balanced budget (expenditure equal to revenues). To simulate this water bank, the following model has been used: 
subject to:

$$
\begin{aligned}
& Q_{p}=Q_{s}=Q_{s a}+Q_{s e} \\
& Q_{p}=Q_{p}\left(P_{p}\right) \\
& Q_{s a}=Q_{s a}\left(P_{s}\right) \\
& P_{p} \cdot Q_{p}=P_{s} \cdot Q_{s a}
\end{aligned}
$$

4.4. Water bank for maximizing economic efficiency considering the social demand for environmental water (Scenario 3)

Scenario 3 represents a water bank aimed at maximizing total economic efficiency $\left(S_{\text {total }}\right)$, also taking into account the surplus generated by resources obtained for environmental uses $\left(S_{s e}\right)$. It incorporates society's demand for environmental water through a demand curve, which shows the willingness to pay for a certain quantity of environmental water $\left(Q_{s e}(V)\right)$, as shown in Figure 2.

Based on the shape of this environmental water demand curve, there are three key questions to be answered: i) what is the maximum value that society would be willing to pay for environmental water $\left(V^{0}\right)$; ii) how much environmental water results in society having a willingness to pay of zero $\left(Q_{s e}^{\max }\right)$; and iii) what is the shape of the curve linking the two aforementioned points (the elasticity of the demand)? Regarding the maximum value that society assigns to environmental water $\left(V^{0}\right)$ there is no robust empirical estimation available. For this reason, the value of this parameter has been parameterized from 0 to 1 euro per cubic meter. Regarding $Q_{s e}^{\max }$, it seems reasonable to assume that society would demand environmental water until current instream flows reach the level of average flows (those registered in an average hydrological year), which in the case of the GRB has been estimated at $7092 \mathrm{Mm}^{3} /$ year (CHG, 2015). As the minimum ecological flow established in the river basin plan is $305 \mathrm{Mm}^{3} /$ year (CHG, 2015), society would be willing to pay to increase this flow up to the point where the average flow is reached. That is, the difference between average flow and minimum ecological flow $\left(6787 \mathrm{Mm}^{3} /\right.$ year $)$ is the maximum quantity of water that society would demand with a non-zero willingness to pay. Finally, we have considered a linear demand curve joining these two extreme points. Although any other shape could be chosen for the demand curve, a linear demand has been simulated for the sake of simplicity.

Having defined society's demand for environmental water $\left(Q_{s e}(V)\right)$, the model simulating the performance of Scenario 3 of the water bank is as follows:

$\operatorname{Max} S_{\text {total }}=S_{p}+S_{s a}+S_{s e}$

subject to: 


$$
\begin{aligned}
& S_{p}=\int_{P_{p}^{0}}^{P_{p}} Q_{p}\left(P_{p}\right) d P_{p} \\
& S_{s a}=\int_{P_{s}}^{P_{s a}^{0}} Q_{s a}\left(P_{s}\right) d P_{s} \\
& S_{s e}=\int_{V}^{V^{0}} Q_{s e}(V) d V+Q_{s e} \cdot V \\
& Q_{p}=Q_{s}=Q_{s a}+Q_{s e} \\
& Q_{p}=Q_{p}\left(P_{p}\right) \\
& Q_{s a}=Q_{s a}\left(P_{s}\right) \\
& Q_{s e}=Q_{s e}^{\max }\left(1-\frac{V}{V^{0}}\right) \\
& P_{p} \cdot Q_{p}=P_{s} \cdot Q_{s a}
\end{aligned}
$$

As explained above, this water bank is aimed at maximizing the total economic efficiency as shown in the objective function (3.1), comprising the three efficiencies or surpluses taken into account: efficiency of purchases $\left(S_{p}\right)$, the efficiency of sales to the agricultural sector $\left(S_{s a}\right)$ and efficiency derived from environmental water recovery $\left(S_{s e}\right)$, as defined in equations (3.2), (3.3) and (3.4). Modeling Scenario 3 also involves the market balance for water quantities (3.5), the supply curve (3.6), agricultural demand curve (3.7) and the linear environmental demand curve (3.8). Finally, (3.9) represents, as in previous models, the required financial balance.

\section{Results}

Table 1 shows the results for Scenario 1 (water bank for the reallocation of resources between productive users), revealing a significantly large net gain in productive efficiency with respect to the baseline scenario, where no trade is allowed. In this scenario, where the water bank acts only as an intermediary between farmers, the maximum productive efficiency gain is achieved by matching purchase and sale prices, thus maximizing consumer and producer surpluses. In this sense, the equilibria reached by a water bank operating in the manner proposed for Scenario 1 are similar to those achieved by a spot water market without transaction costs, as previously explained in Easter and Huang (2014) or Grafton et al. (2011)

\footnotetext{
${ }^{4}$ In this sense, it is worth pointing out that, compared to water markets, water banks foster water transactions in real-life settings because they reduce the transaction costs of operations (Montilla-López et al., 2016).
} 


\section{Table 1}

Results for Scenario 1: Maximum productive efficiency.

\begin{tabular}{clrrr}
\hline & & $\begin{array}{c}\text { Moderate } \\
\text { drought: } \\
\text { A75\% }\end{array}$ & $\begin{array}{r}\text { Severe } \\
\text { drought: } \\
\text { A50\% }\end{array}$ & $\begin{array}{c}\text { Extreme } \\
\text { drought: } \\
\text { A25\% }\end{array}$ \\
\hline $\boldsymbol{P}_{\boldsymbol{p}}$ & Purchase price $\left(€ / \mathrm{m}^{3}\right)$ & 0.15 & 0.26 & 0.40 \\
$\boldsymbol{P}_{\boldsymbol{s}}$ & Sale price $\left(€ / \mathrm{m}^{3}\right)$ & 0.15 & 0.26 & 0.40 \\
$\boldsymbol{Q}_{\boldsymbol{p}}$ & Water quantity purchased $\left(\mathrm{Mm}^{3}\right)$ & 318.63 & 358.87 & 256.64 \\
& (\% of total water availability) & $(16.0 \%)$ & $(27.0 \%)$ & $(38.6 \%)$ \\
$\boldsymbol{Q}_{\boldsymbol{s} \boldsymbol{a}}$ & Water quantity sold $\left(\mathrm{Mm}^{3}\right)$ & 318.63 & 358.87 & 256.64 \\
& (\% of total water availability) & $(16.0 \%)$ & $(27.0 \%)$ & $(38.6 \%)$ \\
$\boldsymbol{Q}_{\boldsymbol{s e}}$ & Environmental water $\left(\mathrm{Mm}^{3}\right)$ & 0.00 & 0.00 & 0.00 \\
$\boldsymbol{S}_{\boldsymbol{p}}$ & (\% of total water availability) & $(0.0 \%)$ & $(0.0 \%)$ & $(0.0 \%)$ \\
$\boldsymbol{S}_{\boldsymbol{s a}}$ & Producer surplus (M€) & 22.32 & 30.71 & 42.76 \\
$\boldsymbol{S}_{\boldsymbol{p r o d}}$ & Productive efficiency gain $(\mathrm{M} €)$ & 18.39 & 25.68 & 16.44 \\
& Total expenditure/revenues $(\mathrm{M} €)$ & 40.72 & 56.40 & 59.21 \\
\hline
\end{tabular}

As expected, the more severe the drought, the higher the equilibrium price. Results also show an increase in the amount of water traded in relative terms as the drought became more acute, ranging from $16.0 \%$ of total water availability in drought scenario A75\% $\left(319 \mathrm{Mm}^{3}\right.$ out of a total of $\left.1995 \mathrm{Mm}^{3}\right)$ to $38.6 \%$ in drought scenario $\mathrm{A} 25 \%\left(257 \mathrm{Mm}^{3} \text { out of } 665 \mathrm{Mm}^{3}\right)^{5}$, likewise leading to an increase in productive efficiency gains, from $40.72 \mathrm{M} €$ for $\mathrm{A} 75 \%$ to 59.21 M€ for A25\%. For a more in-depth analysis of this water bank scenario, interested readers can also refer to the paper by Montilla-López et al. (2018a).

Also regarding Scenario 1, it is worth commenting that it does not involve any change in total water abstraction by productive uses compared with the baseline scenario (water available for the environment remains the same). Thus, this scenario does not involve any change in environmental efficiency, and the productive efficiency gains achieved are also equal to the total economic efficiency gains.

Results for Scenario 2 (maximum volume of water for the environment) are shown in Table 2. The optimum solutions found for the three drought scenarios reveal that it is possible to recover water for environmental purposes using the monopsony-monopoly power of the water bank without any public expenditure, though this capacity is limited. Thus, for a moderate drought (A75\%), $115 \mathrm{Mm}^{3}$ of water can be reallocated in order to increase instream flows,

\footnotetext{
${ }^{5}$ As the reader can note, the share of total water available that it is exchanged ( $\%$ of total water availability) is greater when available water is scarcer (a change from drought scenario A75\% to drought scenario A25\%). However, the volume of water exchanged measured in absolute terms $\left(\mathrm{Mm}^{3}\right)$ follows an inverted U-shaped trend, as already pointed out by Gómez-Limón and Martínez (2006). This non-linear trend can be explained by the fact that the volume of water transferred is the product of the (increasing) share of water to be exchanged and the (decreasing) total water available.
} 
representing $54.6 \%$ of total water purchased by the water bank. However, for more severe droughts, this percentage is lower, accounting for $44.9 \%\left(101 \mathrm{Mm}^{3}\right)$ of total water purchased for drought scenario A50\% and 48.25\% $\left(69 \mathrm{Mm}^{3}\right)$ for drought scenario A25\%. Nevertheless, if the volumes of water recovered for the environment are measured as a percentage of total water available, it can be seen that this share increases when drought scenarios involve lower water availability: $5.8 \%$ of total water availability in scenario A75\%, 7.6\% in scenario A50\% and $10.3 \%$ in scenario A25\%.

\section{Table 2}

Results for Scenario 2: Maximum volume of water for the environment.

\begin{tabular}{clccc}
\hline & & $\begin{array}{c}\text { Moderate } \\
\text { drought: } \\
\mathbf{A 7 5 \%}\end{array}$ & $\begin{array}{c}\text { Severe } \\
\text { drought: } \\
\mathbf{A 5 0 \%}\end{array}$ & $\begin{array}{c}\text { Extreme } \\
\text { drought: } \\
\text { A25\% }\end{array}$ \\
\hline $\boldsymbol{P}_{\boldsymbol{p}}$ & Purchase price $\left(€ / \mathrm{m}^{3}\right)$ & 0.11 & 0.19 & 0.25 \\
$\boldsymbol{P}_{\boldsymbol{s}}$ & Sale price $\left(€ / \mathrm{m}^{3}\right)$ & 0.23 & 0.35 & 0.49 \\
$\boldsymbol{Q}_{\boldsymbol{p}}$ & Water quantity purchased $\left(\mathrm{Mm}^{3}\right)$ & 211.42 & 225.49 & 142.81 \\
& (\% of total water availability) & $(10.6 \%)$ & $(17.0 \%)$ & $(21.5 \%)$ \\
$\boldsymbol{Q}_{\boldsymbol{s} \boldsymbol{a}}$ & Water quantity sold $\left(\mathrm{Mm}^{3}\right)$ & 96.07 & 124.21 & 73.90 \\
& (\% of total water availability) & $(4.8 \%)$ & $(9.3 \%)$ & $(11.1 \%)$ \\
$\boldsymbol{Q}_{\boldsymbol{s e}}$ & Environmental water $\left.(\mathrm{Mm})^{3}\right)$ & 115.35 & 101.28 & 68.91 \\
$\boldsymbol{S}_{\boldsymbol{p}}$ & Producer surplus (M€) & $(5.8 \%)$ & $(7.6 \%)$ & $(10.4 \%)$ \\
$\boldsymbol{S}_{\boldsymbol{s} \boldsymbol{a}}$ & Consumer surplus (M€) & 9.83 & 11.98 & 13.24 \\
$\boldsymbol{S}_{\boldsymbol{p r o d}}$ & Productive efficiency gain $(\mathrm{M} €)$ & 1.67 & 3.14 & 2.52 \\
& Total expenditure/revenue $(\mathrm{M} €)$ & 11.50 & 15.02 & 15.76 \\
\hline
\end{tabular}

In order to recover environmental water without increasing the public budget, the water bank uses its monopsony-monopoly position to create a gap between purchase and sale prices. Thus, compared to Scenario 1, purchase prices are between $0.04 € / \mathrm{m}^{3}(\mathrm{~A} 75 \%)$ and $0.15 € / \mathrm{m}^{3}$ (A25\%) lower, while sale prices are between $0.08 € / \mathrm{m}^{3}$ (A75\%) and $0.09 € / \mathrm{m}^{3}$ (A25\%) higher. This gap leads to a significant decrease in the volume of water traded with respect to Scenario 1 (ranging from a decrease of $34 \%$ in A75\% to $44 \%$ in A25\%). Also, this way of managing the water bank operations also outperforms the situation where there is no water bank in operation (baseline scenario), since efficiency estimates (sum of surpluses accounting for productive efficiency gains) are positive. In any case, productive efficiency gains obtained under this scenario are lower compared to Scenario 1 (lower producer and consumer surpluses), with these differences becoming larger when water availability is lower $(-29.22$ $\mathrm{M} €,-41.38 \mathrm{M} €$, and $-43.45 \mathrm{M} €$ for drought scenarios A75\%, A50\%, and A25\%, respectively).

However, it should be noted that Scenario 2, in addition to yielding productive efficiency gains, also involves environmental efficiency gains due to water recovered for the environment, which have not been estimated since no social demand for environmental water 
has been considered for this scenario. Thus, although total economic efficiency gains have not been estimated, these gains are actually above the productive efficiency gains accounted for in Table 2. Under these conditions, Scenario 1 and 2 cannot be properly compared in terms of economic efficiency.

Finally, regarding Scenario 3 (maximum economic efficiency), optimum solutions depend on the value considered for society's maximum willingness to pay for environmental water $\left(V^{0}\right)$. Figure 4 shows the results obtained for the parameterization of $V^{0}$ in terms of water quantities and prices. In this figure, the resulting curves display two phases or sections. The first phase is found for low values of $V^{0}$ (lower than $0.15,0.26$ and $0.40 € / \mathrm{m}^{3}$ for drought scenarios $\mathrm{A} 75 \%, \mathrm{~A} 50 \%$ and $\mathrm{A} 25 \%$, respectively). In this phase, the only transactions taking place are among farmers, reproducing the solution explained above for Scenario 1. That is, there is a clearing price to buy and sell $\left(P_{p}=P_{s}\right)$ the same quantity of water $\left(Q_{p}=Q_{s a}\right)$ between irrigators. No water is diverted for environmental purposes since its marginal social value is lower than that for productive uses within the farming sector, and thus no net efficiency gains can be achieved by reallocating this water.

(a) Scenario $A 75 \%$

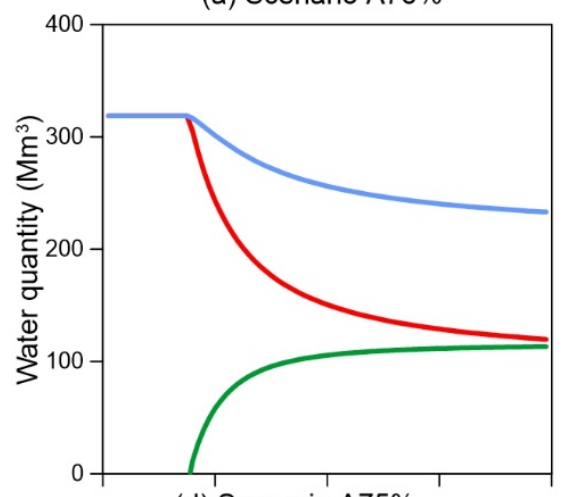

(d) Scenario $A 75 \%$

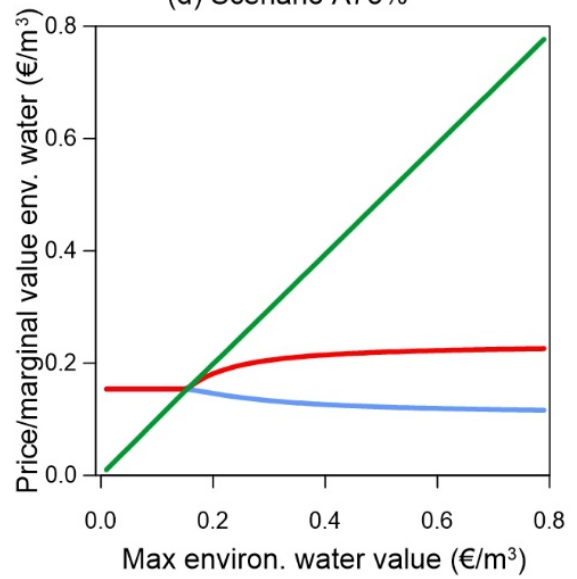

Environmental water (b) Scenario A50\%

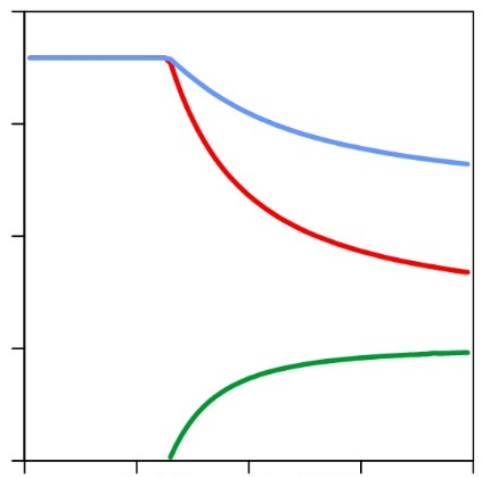

(e) Scenario $A 50 \%$

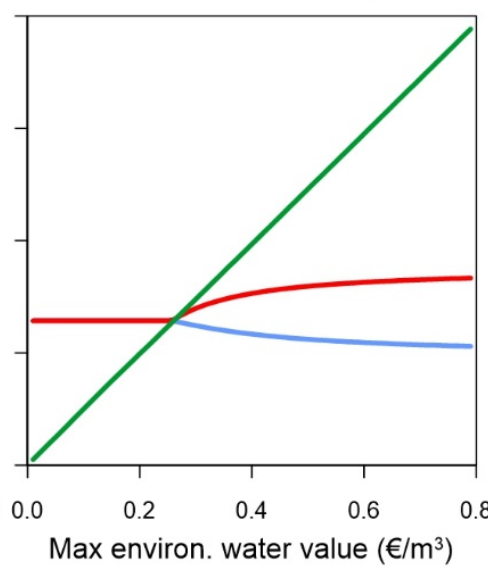

Water sold (c) Scenario A25\%

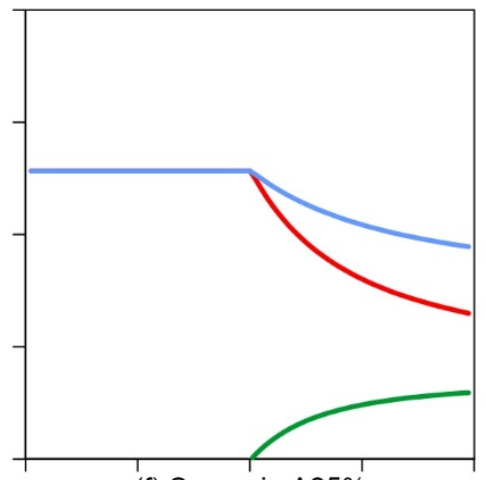

(f) Scenario $A 25 \%$

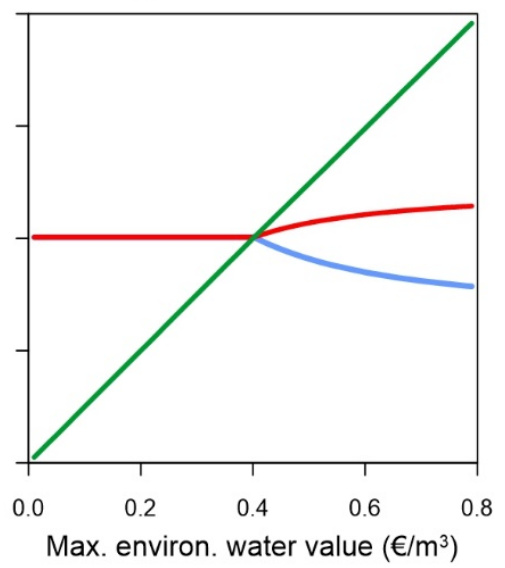

Water purchased

Fig. 4. Results for Scenario 3: Maximizing economic efficiency considering the social demand for environmental water. Volumes of water traded and prices 
The point where $V^{0}$ exceeds the equilibrium price for Scenario 1 marks the start of a second phase, where the volume of water recovered by the bank for environmental purposes increases as this parameter increases, asymptotically approaching the maximum volume reported for Scenario 2. Over the course of this second phase, the volumes of water purchased, and especially water sold, decrease as the amount of water recovered for the environment increases. It can also be observed that the gap between purchase and sale prices grows increasingly wider as $V^{0}$ increases over this phase, asymptotically reaching the difference observed in the optimum solution for Scenario 2. Finally, note that, within the range of $V^{0}$ that defines the second phase, the marginal value of environmental water $(V)$ is higher than the water sale price for agriculture $\left(P_{S}\right)$.

The efficiency performance achieved in Scenario 3 is shown in Figure 5, which depicts the results obtained for the parameterization of $V^{0}$ in terms of economic efficiency. This figure also shows the two phases described above. For the first phase, productive efficiencies $\left(S_{s a}\right.$ and $\left.S_{p}\right)$ are the same as in Scenario 1, while environmental efficiency $\left(S_{s e}\right)$ is null as no water is recovered for the environment. Thus, the total economic efficiency gain $\left(S_{\text {total }}\right)$ also equals the productive efficiency improvement of Scenario 1. Over the second phase, total economic efficiency gains increase compared to the first phase and Scenario 1, despite the decline in productive efficiency gains generated by purchases and sales. This can be explained by the fact that environmental efficiency increases as a result of a rising volume of water diverted by the bank to the environment and the growing value that society assigns to environmental water, and the fact that this increase in environmental efficiency offsets losses in productive efficiency $\left(S_{s a}+S_{p}\right)$. Total economic efficiency increases as $V^{0}$ increases. These results confirm that, from an economic efficiency point of view, the institutional arrangement in water bank Scenario 3 can be considered more efficient than in Scenario 1. 
(a) Scenario $A 75 \%$

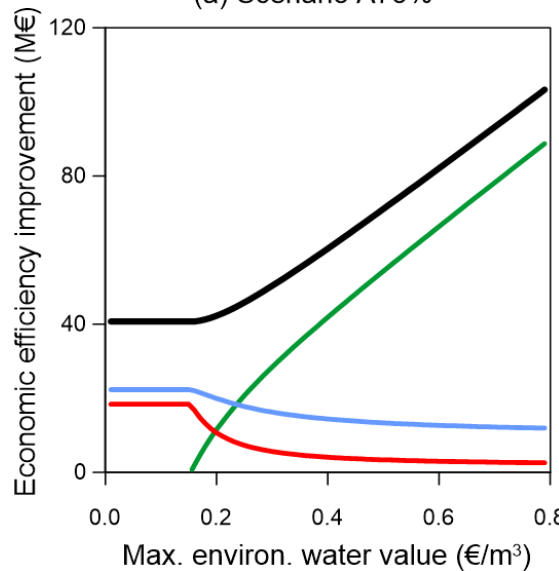

Max. environ. water value $\left(€ / \mathrm{m}^{3}\right)$ (b) Scenario A50\%

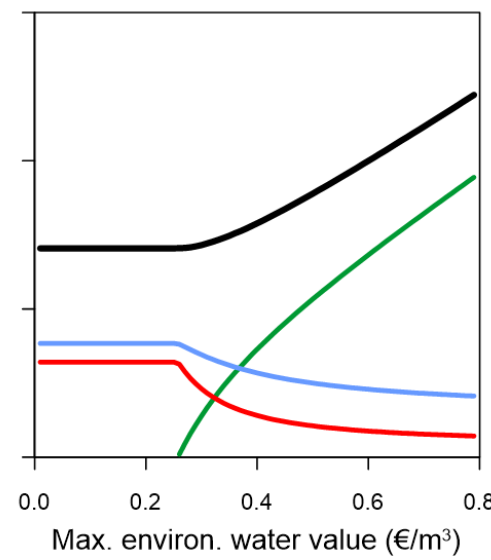

(c) Scenario A25\%

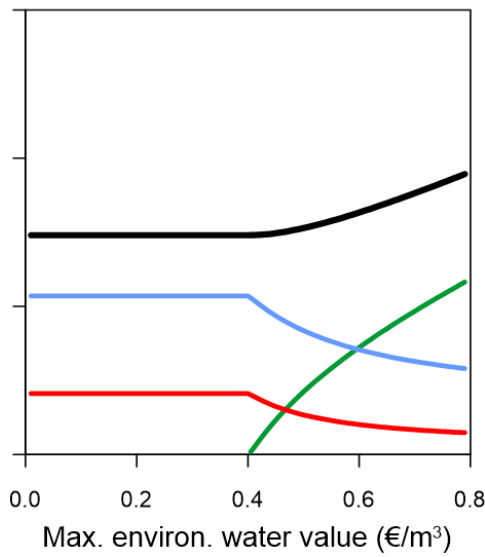

$\begin{array}{lll}- \text { Efficiency of sales }\left(\mathrm{S}_{\mathrm{sa}}\right) & \text { Environmental efficiency }\left(\mathrm{S}_{\mathrm{se}}\right) \\ \text { Efficiency of purchases }\left(\mathrm{S}_{\mathrm{p}}\right) & \text { Total economic efficiency }\left(\mathrm{S}_{\text {total }}\right)\end{array}$

Fig. 5. Results for Scenario 3: Maximizing economic efficiency considering the social demand for environmental water. Efficiency gains

\section{Discussion}

As pointed out above, drought episodes have the potential to cause serious environmental damages, especially when minimum environmental flows are not properly set and enforced. In such cases, the proposed self-financed water banks (Scenarios 2 and 3) can be considered as interesting policy measures to minimize these damages, by diverting water from productive uses to environmental uses without requiring any public budget to do so. While Scenario 2 shows the maximum amount of water that can be recovered for the environment, Scenario 3 illustrates how much of the water traded should be diverted to the environment in order to maximize total economic efficiency, depending on the value that society assigns to environmental water. The efficiency analysis of Scenario 3 has shown that, from an economic efficiency perspective, this bank design can offer optimal solutions regarding water allocation between productive and environmental uses. This is despite the monopsony-monopoly setting proposed for this water bank, since the decline in productive efficiency gains generated by purchases and sales between productive uses is more than offset by the efficiency gains due to environmental water recovery. Thus, this an example of how a statutory monopsonymonopoly setting can lead to maximum economic efficiency if this market power is properly harnessed by a public agency in order to achieve the stated objective (Roemer and Silvestre, 1992).

These findings suggest that the proposed bank in Scenario 3 is particularly suitable for coping with drought episodes in closed basins where: a) no trade allocation instruments have been implemented previously (baseline scenario as benchmark); b) there is a relatively low marginal productivity of water in productive uses ('short' first phase regarding the 
parameterization of $V^{0}$ ); and c) water ecosystems are not very resilient to drought, leading to a high societal demand for environmental water in the event of water scarcity.

As shown above, the operational implementation of the water bank proposed in Scenario 3 would rely on having an accurate enough estimate of society's demand for environmental water. Nevertheless, it is not easy to establish the value society assigns to environmental water for each scenario of water scarcity. To this end, it would be necessary to carry out specific studies using environmental valuation methods such as contingent valuation or choice experiments, since no useful data is currently available in the literature for this purpose. The work of Martín-Ortega et al. (2009) is worth citing, simply in order to frame the valuation exercises needed in the GRB. These authors assessed the willingness to pay for the improvement of the water quality in this basin, using contingent valuation. According to their results, the aggregate willingness to pay at basin level for the improvement of water quality ranges from 48.0 $\mathrm{M} €$ annually (for the achievement of 'good' quality water, i.e., suitable for swimming and fishing) to $59.5 \mathrm{M} € /$ year (for 'very good' quality-suitable for drinking). Taking into account that water quality and quantity are closely related, this range of aggregate values demonstrates the existing social demand for environmental water that can improve the ecological status of water bodies, even under a normal hydrological situation. In any case, these value estimates cannot be used to elicit society's demand curve for environmental water for two reasons. First, because water quality is related to current pollution issues (negative externalities produced by water users), while water quantity issues are contingent on climate conditions (drought periods), which cannot properly be considered as an 'externality' generated by third-party economic agents. This could prompt society to view quality and quantity issues differently and thus lead to divergent value estimates. And second, because the valuation exercise regarding water quality has been implemented for a scenario of normal hydrological conditions, thus making it impossible to relate social demand with different levels of environmental damage related to drought scenarios (quantity issues).

Another point for discussion concerns the assumptions and limitations of the modeling exercise performed. In this sense, it is worth mentioning several factors that could explain a less-than-optimal performance in a real-life setting: i) aggregation bias, ii) transaction costs, and iii) different barriers to water trading.

Modeling farming activity at any level other than that of the individual farm implies problems of aggregation bias (Hazell and Norton, 1986). Our modeling approach has tried to minimize this bias by considering different irrigated farm types as modeling units. However, this aggregation bias can only be fully avoided if all the farms included in each farm type fulfill strict homogeneity criteria (technological homogeneity, pecuniary proportionality, and institutional proportionality), requirements that it is impossible to entirely meet. Thus, aggregated simulation results tend to overestimate the efficiency improvements that can be achieved, since the aggregated programming models built overestimate resource mobility by 
enabling farms to combine resources in proportions not actually available to them at an individual level and assuming that all the aggregated farms have equal access to the same technologies of production.

Another important factor that would limit the potential performance of the water bank proposed is transaction costs. Montilla-López et al. (2018a) have simulated the impact of operational transaction costs on the performance of a water bank for allocation trade within the agricultural sector (similar to Scenario 1) in the same river basin (GRB). Assuming these transaction costs account for $0.02 € / \mathrm{m}^{3}$ (Garrido, 2000) of every purchase and sale operation, these authors show a decrease in the amount of water exchanged of around $13 \%$ in a situation of severe drought (A50\%), and $9 \%$ in the case of extreme drought (A25\%) relative to a situation with zero transaction costs. Since our modeling approach has ignored the existence of transaction costs, it is also expected that, the total economic efficiency gains achieved by the proposed bank in a real setting would be around $10 \%$ lower than reported.

Finally, it is also worth mentioning that some physical, cultural and psychological barriers to water transactions are difficult to model and have also been omitted from this empirical exercise. For instance, regarding physical barriers, it is possible that certain water transactions modeled could not be carried out in the real world because in some cases, the amount of water actually available at local level could be lower than the amount allocated by the model. The simplifying assumption that water available at basin level can be allocated anywhere, could also entail an overestimation of the water transactions performed through the water banks. Similarly, the limited experience of water trading in the GRB could make farmers wary of such a proposal, thus creating cultural and psychological barriers to water transactions (Giannoccaro et al., 2013; Giannoccaro et al., 2015).

Having explicitly noted the limitations of the modeling approach followed, the final point for discussion concerns the reliability of the results obtained. For this purpose, it is worth comparing these results with the empirical evidence available from the actual implementation of similar instruments in other Spanish basins. A case in point is the water exchange centers (water bank for allocation trade) created in the Segura and Jucar basins during the drought period 2007-2008, aimed at purchasing water allocations for environmental purposes using public budgetary resources. The performance of both these environmentally-focused water banks has been critically analyzed in Montilla-López et al. (2017). In 2007, in the Jucar basin, when the drought episode was qualified as 'severe' (similar to drought scenario A50\%), 27.3 $\mathrm{Mm}^{3}$ of water was recovered for the environment at a price of $0.19 € / \mathrm{m}^{3}$, with a total cost of 5.2 M€. The purchase price fixed is in line with those obtained $\left(P_{p}\right)$ for the same drought scenario (A50\%). During 2008, when the drought was more intense and was classified as 'extreme' (similar to A25\%), $50.6 \mathrm{Mm}^{3}$ of water was recovered at a price of $0.25 € / \mathrm{m}^{3}$, representing a cost of $12.7 \mathrm{M} €$ to the public budget. This price is also close to the purchase prices obtained in our simulation of the self-financed water bank proposed under Scenario 3 
for an extreme drought. In the Segura basin, the water bank created for environmental purposes reported a similar performance, with a purchase price fixed at $0.17 € / \mathrm{m}^{3}$. These market prices reflect the sale position of the agricultural sector (shape of the water supply curve $Q_{p}$ in our modeling approach), revealing a high degree of consistency with the results of the modeling exercise performed for this research.

Regarding the reliability of the sale price to the agricultural sector $\left(P_{S}\right)$, it has been found that, in the Segura basin, between 0.50 and $0.65 € / \mathrm{m}^{3}$ is paid for desalinated water (MartínezAlvarez et al., 2018). These sale prices are indeed higher than those obtained from our simulation models. The existing gap can be explained by the difference in agricultural water productivity between the Segura and Guadalquivir basins. In any case, this evidence suggests that the agricultural sector's willingness to pay for water can reach high prices when resource availability is scarce.

The evidence highlighted here suggests that the results reported in this research can be considered reliable enough to support policy-making. However, it is worth pointing out that the scope for practical application and the related modeling approach could be further explored in order to achieve more accurate results. In this sense, the ex-ante assessment of the water bank proposed could be improved by performing the analysis at sub-basin level (less aggregation bias), and properly accounting for transaction costs and other barriers to trade.

\section{Concluding remarks}

The proposed self-financed water bank with the twofold objective of reallocating water between farmers and recovering water for environmental purposes (Scenario 3) can be considered an interesting policy option from an efficiency point of view. Indeed, it is even more efficient than a water bank solely focused on reallocating water among farmers. More specifically, when the society's maximum marginal value for environmental water is above the competitive market equilibrium price, the proposed water bank aimed at maximizing economic efficiency outperforms a water bank that reallocates water within the agricultural sector. In addition, the former is as good as the latter when the maximum marginal value for environmental water is below the competitive market price.

The implementation of this water bank can also be justified for socio-political and administrative reasons. First, it is worth pointing out that from society's point of view, paying compensation to farmers to recover water for the environment is hard to defend because: i) water rights were granted to farmers for free by the public agency responsible for basin management; and ii) water scarcity and related environmental problems are the results not only of natural causes but also the overallocation of water rights (badly managed water rights system because of private lobbying) (Hernández-Mora and Del Moral, 2015; Palomo-Hierro et al., 2015). In this sense, the proposed water bank could be readily accepted by the public since it does not entail spending public money on acquiring allocations to fix environmental 
problems related to water scarcity. Second, from an administrative point of view, this institutional setting for the water bank could also be appealing given the difficulties involved (policy debate, budget constraints, approval procedure, etc.) in securing the necessary public budget to recover water for the environment during drought episodes. Indeed, such procedural hurdles could prevent the recovery from being carried out in time. Thus, this dual-purpose self-financed bank provides a pragmatic option to overcome these kinds of problems.

Notwithstanding the bank's promising features, it should also be noted that the implementation of the proposed water bank in a real-life setting is challenging since it requires good-quality data inputs, especially regarding farmers' water allocation demand and supply and society's demand for environmental water. Thus, in order to achieve the maximum efficiency performance theoretically explained in this paper, further research is needed to accurately describe the demand for water for the environment.

\section{Acknowledgments}

The authors are particularly grateful to the anonymous reviewers for their very helpful comments on previous versions of the paper. The authors also acknowledge financial support from the Spanish Ministry of Science, Innovation and Universities (MCIU) and the European Regional Development Fund (ERDF) through the research project IRRIDROUGHT (RTI2018-095407-B-I00).

\section{References}

Bark, R., Kirby, M., Connor, J.D., Crossman, N.D., 2014. Water allocation reform to meet environmental uses while sustaining irrigation: a case study of the Murray-Darling Basin, Australia. Water Policy 16, 739-754. http://doi.org/10.2166/wp.2014.128.

Berbel, J., Pedraza, V., Giannoccaro, G., 2013. The trajectory towards basin closure of a European river: Guadalquivir. Int. J. River Basin Manage. 11, 111-119. http://doi.org/10.1080/15715124.2013.768625.

Burke, S.M., Adams, R.M., Wallender, W.W., 2004. Water banks and environmental water demands: Case of the Klamath project. Water Resour. Res. 40, W09S02. http://doi.org/10.1029/2003WR002832.

CHG (Confederación Hidrográfica del Guadalquivir), 2015. Plan Hidrológico de la Demarcación del Guadalquivir (2015-2021). Confederación Hidrográfica del Guadalquivir, Sevilla.

Connor, J.D., Franklin, B., Loch, A., Kirby, M., Wheeler, S.A., 2013. Trading water to improve environmental flow outcomes. Water Resour. Res. 49, 4265-4276. http://doi.org/10.1002/wrcr.20323.

Connor, J.D., Kaczan, D., 2013. Principles for economically efficient and environmentally sustainable water markets: The Australian experience, in: Schwabe, K., Albiac, J., Connor, J.D., Hassan, R.M., Meza González, L. (Eds.), Drought in arid and semi-arid regions. Springer, Dordrecht, The Netherlands, pp. 357-374. http://doi.org/10.1007/978-94-007-6636-5 20.

Crase, L., O’Keefe, S., Kinoshita, Y., 2012. Enhancing agrienvironmental outcomes: Market-based approaches to water in Australia's Murray-Darling Basin. Water Resour. Res. 48, W09536. http://doi.org/10.1029/2012WR012140.

Crossman, N.D., Connor, J.D., Bryan, B.A., Summers, D.M., Ginnivan, J., 2010. Reconfiguring an irrigation landscape to improve provision of ecosystem services. Ecol. Econ. 69, 1031-1042. http://doi.org/10.1016/j.ecolecon.2009.11.020. 
Easter, K.W., Huang, Q., 2014. Water markets for the 21st century: What have we learned? Springer, New York. http://doi.org/10.1007/978-94-017-9081-9.

Expósito, A., Berbel, J., 2017. Agricultural irrigation water use in a closed basin and the impacts on water productivity: The case of the Guadalquivir river basin (Southern Spain). Water 9, 136. http://doi.org/10.3390/w9020136.

Garrido, A., 2000. A mathematical programming model applied to the study of water markets within the Spanish agricultural sector. Ann. Oper. Res. 94, 105-123. http://doi.org/10.1023/A:1018965016134.

Giannoccaro, G., Castillo, M., Berbel, J., 2015. An assessment of farmers' willingness to participate in water trading in southern Spain. Water Policy 17, 520-537. http://doi.org/10.2166/wp.2014.092.

Giannoccaro, G., Pedraza, V., Berbel, J., 2013. Analysis of stakeholders attitudes towards water markets in the south of Spain. Water 5, 1517-1532. http://doi.org/10.3390/w5041517.

Gómez-Limón, J.A., Martínez, Y., 2006. Multi-criteria modelling of irrigation water market at basin level: A Spanish case study. Eur. J. Oper. Res. 173, 313-336. http://doi.org/10.1016/j.ejor.2004.12.009.

Grafton, R.Q., Libecap, G.D., McGlennon, S., Landry, C.J., O’Brien, R.J., 2011. An integrated assessment of water markets: A cross-country comparison. Rev. Env. Econ. Policy 5, 219-239. http://doi.org/10.1093/reep/rer002.

Grafton, R.Q., Wheeler, S.A., 2018. Economics of water recovery in the Murray-Darling Basin, Australia. Annu. Rev. Resour. Econ. 10, 3.1-3.24. http://doi.org/10.1146/annurev-resource100517-023039.

Hafi, A., Beare, S.C., Heaney, A., Page, S., 2005. Water options for environmental flows. Australian Bureau of Agricultural and Resource Economics, Canberra.

Hanak, E., Stryjewski, E., 2012. California's water market, by the numbers: Update 2012. Public Policy Institute of California, San Francisco.

Hazell, P.B.R., Norton, R.D., 1986. Mathematical programming for economic analysis in agriculture. MacMillan Publishing Company, New York.

Hernández-Mora, N., Del Moral, L., 2015. Developing markets for water reallocation: Revisiting the experience of Spanish water mercantilización. Geoforum 62, 143-155. http://doi.org/10.1016/j.geoforum.2015.04.011.

Kirby, M., Qureshi, M.E., Mainuddin, M., Dyack, B., 2006. Catchment behaviour and counter-cyclical water trade: An integrated model. Nat. Resour. Model 19, 483-510. http://doi.org/10.1111/j.1939-7445.2006.tb00191.x.

Lago, M., Mysiak, J., Gómez, C.M., Delacámara, G., Maziotis, A., 2015. Use of economic instruments in water policy: Insights from international experience. Springer, Cham, Switzerland. http://doi.org/10.1007/978-3-319-18287-2.

Lane-Miller, C.C., Wheeler, S.A., Bjornlund, H., Connor, J., 2013. Acquiring water for the environment: Lessons from natural resources management. J. Environ. Pol. Plan. 15, 513-532. http://doi.org/10.1080/1523908x.2013.807210.

Martín-Ortega, J., Berbel, J., Brouwer, R., 2009. Economic assessment of non-market environmental benefits of water quality: An application of the Water Framework Directive to the Guadalquivir River Basin. Economía Agraria y Recursos Naturales (Agricultural and Resource Economics) 9, 65-89. http://doi.org/10.7201/earn.2009.01.04.

Martínez-Alvarez, V., González-Ortega, M.J., Martin-Gorriz, B., Soto-García, M., Maestre-Valero, J.F., 2018. Seawater desalination for crop irrigation. Current status and perspectives, in: Gude, V.G. (Ed.), Emerging technologies for sustainable desalination Handbook. ButterworthHeinemann, Oxford, UK, pp. 461-492. http://doi.org/10.1016/B978-0-12-815818-0.00014-X.

McCann, L., Colby, B., Easter, K.W., Kasterine, A., Kuperan, K.V., 2005. Transaction cost measurement for evaluating environmental policies. Ecol. Econ. 52, 527-542. http://doi.org/10.1016/j.ecolecon.2004.08.002.

Medellín-Azuara, J., Howitt, R.E., Lund, J.R., 2013. Modeling economic-engineering responses to drought: The California case, in: Schwabe, K., Albiac, J., Connor, J.D., Hassan, R.M., Meza González, L. (Eds.), Drought in arid and semi-arid regions. A multi-disciplinary and cross- 
country perspective. Springer, Dordrecht, The Netherlands, pp. 341-356. http://doi.org/10.1007/978-94-007-6636-5.

Molle, F., Wester, P., Hirsch, P., 2010. River basin closure: Processes, implications and responses. Agr. Water Manage. 97, 569-577. http://doi.org/10.1016/j.agwat.2009.01.004.

Montilla-López, N.M., Gómez-Limón, J.A., Gutiérrez-Martín, C., 2017. Los bancos de agua como instrumento económico para la mejora de la gestión del agua en España. Revista Española de Estudios Agrosociales y Pesqueros 247, 95-135.

Montilla-López, N.M., Gómez-Limón, J.A., Gutiérrez-Martín, C., 2018a. Sharing a river: Potential performance of a water bank for reallocating irrigation water. Agricultural Water Management 200, 47-59. http://doi.org/10.1016/j.agwat.2017.12.025.

Montilla-López, N.M., Gómez-Limón, J.A., Gutiérrez-Martín, C., 2018b. Simulating farmers' decision-making with a Cobb-Douglass MAUF: An application for an ex-ante policy analysis of water pricing, in: Berbel, J., Bournaris, T., Manos, B., Matsatsinis, N., Viaggi, D. (Eds.), Multicriteria analysis in agriculture. Current trends and recent applications. Springer International Publishing AG, Cham, Switzerland, pp. 199-221. http://doi.org/10.1007/978-3319-76929-5.

Montilla-López, N.M., Gutiérrez-Martín, C., Gómez-Limón, J.A., 2016. Water banks: What have we learnt from the international experience? Water 8, 466. http://doi.org/10.3390/w8100466.

Palomo-Hierro, S., Gómez-Limón, J.A., Riesgo, L., 2015. Water markets in Spain: Performance and challenges. Water 7, 652-678. http://doi.org/10.3390/w7020652.

Pérez-Blanco, C.D., Gutiérrez-Martín, C., 2017. Buy me a river: Use of multi-attribute non-linear utility functions to address overcompensation in agricultural water buyback. Agr. Water Manage. 190, 6-20. http://doi.org/10.1016/j.agwat.2017.05.006.

Pindyck, R.S., Rubinfeld, D.L., 2013. Microeconomics (8th Ed.). Pearson Education, Inc., Upper Saddle River, New Jersey.

Qureshi, M.E., Connor, J., Kirby, M., Mainuddin, M., 2007. Economic assessment of acquiring water for environmental flows in the Murray Basin. Aust. J. Agr. Resour. Econ. 51, 283-303. http://doi.org/10.1111/j.1467-8489.2007.00383.x.

Roemer, J.E., Silvestre, J., 1992. A welfare comparison of private and public monopoly. J. Public Econ. 48, 67-81. http://doi.org/10.1016/0047-2727(92)90042-E.

Schilizzi, S., Latacz-Lohmann, U., 2013. Conservation tenders: linking theory and experiments for policy assessment. Aust. J. Agr. Resour. Econ. 57, 15-37. http://doi.org/10.1111/j.14678489.2012.00602.x.

Scoccimarro, M., Collins, D., 2006. Natural resource 'buybacks' and their use to secure environmental flows. Australian Government, Canberra.

Wilhite, D.A., Glantz, M.H., 1985. Understanding the drought phenomenon: The role of definitions. Water Int. 10, 111-120. http://doi.org/10.1080/02508068508686328. 